\title{
Alteration of Renal Natriuretic Systems Is Associated with the Development of Hypertension and Precedes the Presence of Renal Damage in a Model of Metabolic Syndrome
}

\author{
La alteración de sistemas natriuréticos renales se asocia con el desarrollo de hipertensión arterial \\ y precede en el tiempo a la aparición de daño renal en un modelo de síndrome metabólico
}

NATALIA L. RUKAVINA MIKUSIC ${ }^{1,2}$, NICOLÁS M. KOUYOUMDZIAN ${ }^{1,2}$, JULIETA S. DEL MAURO ${ }^{3}$, MARIELA M. GIRONACCI $^{4}$, ANA M. PUYÓ2, 5, JORGE E. TOBLLI ${ }^{1,6}$, BELISARIO E. FERNÁNDEZ ${ }^{1,2}$, MARCELO R. CHOI 12,5

\begin{abstract}
Background: The aim of this study was to determine the presence of alterations in the natriuretic systems of atrial natriuretic peptide and renal dopamine in a model of metabolic syndrome induced by fructose overload and to associate them with changes in systolic blood pressure, renal function, $\mathrm{Na}+\mathrm{K}+$-ATPase status and microalbuminuria.

Methods: Male Sprague-Dawley rats were divided into control (C) and fructose (F) groups receiving drinking water or a fructose solution (10\% W/V), respectively, for 4, 8 and 12 weeks. L-dopa and dopamine, sodium, creatinine and albumin were measured in urine and ANP, insulin, sodium and creatinine in plasma. Systolic blood pressure was measured by indirect method and the renal activity and expression of $\mathrm{Na}+/ \mathrm{K}+$-ATPase as well as the renal expression of A- and C-type natriuretic peptide receptors were assessed. Results: Fructose overload was associated with a significant increase in insulinemia and systolic blood pressure levels and a decrease in urinary sodium excretion since week 4. A significant increase in L-dopa excretion and a decrease in dopamine excretion (increased urinary L-dopa/dopamine ratio) due to fructose overload were observed since week 4 with a decrease in plasma atrial natriuretic peptide at weeks 8 and 12. These changes were accompanied by increased activity and expression of $\mathrm{Na}+/ \mathrm{K}+-\mathrm{ATPase}$, decreased A-type natriuretic peptide receptor and increased C-type natriuretic peptide receptor expression. Microalbuminuria was observed at week 12 of fructose overload.

Conclusions: Altered atrial natriuretic peptide and renal dopamine were associated with the development of hypertension and preceded in time the presence of microalbuminuria, thus establishing a temporal association between the alteration of both systems and the development of renal damage.
\end{abstract}

Keywords: Dopamine - Atrial natriuretic peptide - Kidney - Fructose - Hypertension - Microalbuminuria

RESUMEN

Objetivos: El objetivo del trabajo consistió en determinar la existencia de alteraciones en los sistemas natriuréticos del péptido natriurético atrial y dopamina renal en un modelo de síndrome metabólico por sobrecarga de fructosa y asociarlas con cambios en la presión arterial sistólica, función renal, estado de la $\mathrm{Na}+, \mathrm{K}+$-ATPasa y microalbuminuria.

Material y Métodos: Ratas macho Sprague-Dawley fueron divididas en grupos control (C) y fructosa (F) con agua o solución de F $(10 \% \mathrm{P} / \mathrm{V})$ para beber durante 4, 8 y 12 semanas. En orina, se midió L-dopa y dopamina, sodio, creatinina y albúmina; y en plasma péptido natriurético atrial, insulina, sodio y creatinina. La presión arterial sistólica fue medida por método indirecto. Se midió la actividad y expresión de la $\mathrm{Na}+, \mathrm{K}+$-ATPasa así como la expresión del receptor de péptidos natriuréticos A y C renales.

Resultados: La sobrecarga de fructosa se asoció con el aumento de la insulinemia y la presión arterial sistólica, y con la disminución en la excreción urinaria de sodio desde la semana 4. La excreción urinaria de L-dopa se incrementó y la de dopamina disminuyó (cociente L-dopa/dopamina incrementado) por sobrecarga de fructosa desde la semana 4 y el péptido natriurético atrial plasmático se redujo en las semanas 8 y 12 . Estos cambios fueron acompañados por un incremento de la actividad y expresión de la $\mathrm{Na}+, \mathrm{K}+-$ ATPasa, disminución del receptor de péptidos natriuréticos A y aumento del C. La microalbuminuria se observó en la semana 12 de sobrecarga de fructosa.

Rev ARGENT CARDIOL 2018;86:6-12. http://dx.doi.org/10.7775/rac.v86.i1.11331

Received: 10/25/2017 - Accepted: 11/29/2017

Address for reprints: Natalia Lucía Rukavina Mikusic. Instituto de Investigaciones Cardiológicas (ININCA), Universidad de Buenos Aires, CONICET Marcelo T. de Alvear 2270 - C1122AAJ CABA, Buenos Aires, Argentina. Tel: (54 11) 4508-3880 - E-mail: naty_rkv@hotmail.com

This work received the 2017 Braun Menéndez Award.

Financial support: This work was supported by ANPCYT (PICT 2012-1775) and Universidad de Buenos Aires (UBACYT 20020110200048 and 20020130200105BA) grants and the Argentine Society of Hypertension 2014-2015 research on hypertension incentive grant.

\footnotetext{
${ }^{1}$ Universidad de Buenos Aires (UBA). CONICET. Institute of Cardiologic Research (ININCA).

${ }^{2}$ UBA. Institute of Physiopathology and Clinical Biochemistry (INFIBIOC)

${ }^{3}$ UBA. School of Pharmacy and Biochemistry (FFyB). Chair of Pharmacology.

${ }^{4}$ UBA. FFyB. Chair of Biological Chemistry.

${ }^{5}$ UBA. FFyB. Chair of Anatomy and Histology.

${ }^{6}$ Hospital Alemán. Laboratory of Experimental Medicine
} 
Conclusiones: Las alteraciones del péptido natriurético atrial y de la dopamina renal se asociaron con el desarrollo de hipertensión arterial y precedieron a la aparición de microalbuminuria, por lo que se pudo establecer una asociación temporal entre la alteración de ambos sistemas y el desarrollo de daño renal.

Palabras clave: Dopamina - Péptido natriurético atrial - Riñón - Fructosa - Hipertensión - Microalbuminuria

Abbreviations

\begin{tabular}{ll|ll} 
ANP & Atrial natriuretic peptide & NPRA & A-type natriuretic peptide receptor \\
C & Control group & NPRC & C-type natriuretic peptide receptor \\
ClCr & Creatinine clearance & PKG & Protein kinase G \\
F & Fructose overload group & SBP & Systolic blood pressure \\
HRLC & High-resolution liquid chromatography & SF & Fructose overload \\
NBCe1 & Type 1 $\mathrm{Na+-HCO3-} \mathrm{cotransporter}$ & UNaV & Urinary sodium excretion. \\
NHE3 & Type 3 $\mathrm{Na}+$ /H+ exchanger & & \\
\end{tabular}

\section{INTRODUCTION}

Hypertension is the most prevalent chronic disease with worldwide incidence and one of the cardiovascular risk factors that takes part in the definition of metabolic syndrome. $(1,2)$ It has been shown that altered renal excretion of sodium has vital importance in the pathogenesis of hypertension. (3) Renal dopamine and the atrial natriuretic peptide (ANP) are two natriuretic systems capable of modifying renal sodium management through the regulation of various sodium ion transporters in tubular cells. $(3,4)$ Among these cells, proximal tubular cells are able to synthesize dopamine from the uptake and subsequent decarboxylation of the L-dopa precursor by dopa decarboxylase. (5) Under basal conditions, more than $50 \%$ of the renal excretion of sodium is regulated by the activation of dopamine- mediated D1 receptors. (6) On the other hand, ANP exerts its natriuretic action by activating the A-type natriuretic peptide receptor (NPRA) in the kidneys. (7) The atrial natriuretic peptide can also bind to the C-type natriuretic peptide receptor (NPRC), which is considered a clearing receptor that mediates the degradation of this peptide. (8) During the last decade, numerous studies have suggested the possible existence of an interaction between natriuretic peptides and the renal dopaminergic system. $(9,10)$. In this sense, it has been reported that renal dopamine and ANP can achieve their natriuretic effects through a common pathway that involves the reversible deactivation of renal $\mathrm{Na}+/$ $\mathrm{K}+$-ATPase, an enzyme whose alteration is closely related to saline retention. $(11,12)$

On the other hand, it is estimated that about 30$50 \%$ of hypertensive patients have insulin resistance. $(1,13)$ Several studies have established an association between insulin resistance and alterations in the renal dopaminergic system in the genesis of hypertension. (14) It has been demonstrated that rats with insulinresistance due to fructose overload (FO) have lower urinary excretion of dopamine, which inversely correlates with blood pressure levels. (15) Likewise, several studies have confirmed a correlation between low levels of ANP and high levels of glucose and insulin, as well as of cholesterol and plasma triglycerides. (16,
17) However, there is little evidence about the interaction between renal dopamine and ANP in the physiopathology of hypertension induced by a high fructose diet. Moreover, the kidney is one of the target organs of hypertension, and microalbuminuria is currently an early indicator of nephropathy and a predictor of ischemic heart disease in essential hypertension. (18) In this context, the association between metabolic syndrome, insulin resistance and renal damage has been demonstrated. $(19,20)$

The aim of this work was to determine whether alterations in the natriuretic systems of ANP and renal dopamine in insulin-resistant rats due to high fructose diet are associated with changes in systolic blood pressure and renal tubular function, increased activity or expression of renal $\mathrm{Na}+/ \mathrm{K}+$-ATPase and the presence of microalbuminuria as a marker of renal structural damage.

\section{METHODS}

Experimental animals

Male Sprague-Dawley rats weighing 150 to $180 \mathrm{~g}$ were used, with $12: 12 \mathrm{~h}$ light/dark cycles, at $22^{\circ} \mathrm{C}$, and fed with a balanced diet for rodents.

\section{Systolic blood pressure assessment}

The animals were trained three times a week in the procedure of blood pressure assessment. Systolic blood pressure (SBP) was determined before beginning the study and at the end of each experimental period through indirect plethysmographic method by means of a sphygmomanometer in the rat tail, using an inflatable cuff and a microphone connected to a Grass DC amplifier (model 7DAC, Grass Instruments Co.) coupled to a polygraph (model 79D, Grass Instruments Co.).

\section{Collection and processing of urine and blood samples}

At the end of each experimental period, 24-hour urine samples were collected from the animals housed in metabolic cages, to determine 24-hour urine output and the urinary excretion of sodium, creatinine, albumin, L-dopa and dopamine. Before sacrifice and under intraperitoneal anesthesia with ketamine $(80 \mathrm{mg} / \mathrm{kg})$ and xylazine $(12 \mathrm{mg} / \mathrm{kg})$, blood samples were collected from the retroocular plexus and centrifuged at $2700 \mathrm{rpm}$ for 20 minutes at $4^{\circ} \mathrm{C}$. Plasma and 
urinary concentrations of sodium, creatinine and albumin were determined in an automated autoanalyzer (Spectrum CCX automated analyzer, diagnostic Abbott) by spectrophotometric method. Plasma insulin levels were determined by ELISA (Millipore Corporation) and plasma levels of ANP by ELISA ( $R$ \& D Systems), after extraction by reverse phase chromatography with Sep-Pak C18 cartridges, according to the purification methodology of Sarda et al. (21)

\section{L-dopa and dopamine concentration assessment}

Assessment of the urinary concentration of L-dopa and dopamine was performed by stabilization with $1 \mathrm{M}$ acetic acid ( $\mathrm{pH}$ 6.10), recovery in alumina and separation by reversedphase high-performance liquid chromatography (RP-HPLC) using $4.6 \mathrm{~mm} \times 25 \mathrm{~cm}$ columns (Beckman Instruments). Catecholamines were quantified by amperometric detection with $0.65 \mathrm{~V}$ Bioanalytical Systems electrode versus $\mathrm{Ag} / \mathrm{Ag}$ reference electrodes.

\section{Renal function parameter assessment}

Plasma and urinary sodium and creatinine values were used to assess renal function parameters. Glomerular filtration rate was estimated by creatinine clearance and tubular function by urinary sodium excretion.

\section{Renal tissue collection and processing}

Immediately after sacrifice, both kidneys were removed from each animal and decapsulated. Sections of both kidneys were obtained and stored at $-80^{\circ} \mathrm{C}$ for western blot analyses and specific activity of $\mathrm{Na}+/ \mathrm{K}+$-ATPase.

\section{Protein expression analysis by western blot technique}

Protein expression was semiquantitatively analyzed using western blot technique, as previously described. (22) Renal expression of $\mathrm{Na}+/ \mathrm{K}+$-ATPase was determined using anti$\mathrm{Na}+/ \mathrm{K}+$-ATPase antibody (Amersham, dilution 1: 8000), renal expression of NPRA, using anti-NPRA antibody (Santa Cruz Biotechnology, dilution 1: 7500), and expression of NPRC, using anti-NPRC antibody (Santa Cruz Biotechnology, dilution 1: 400). Biotinylated IgG anti-rabbit antibody (GE Healthcare Life Sciences, dilution 1: 2000) and streptavidin conjugated with radish peroxidase (GE Healthcare Life Sciences, dilution of 1: 2000) were used for secondary and tertiary reactions, respectively. The samples were revealed by chemiluminescence using ECL reagent (Amersham Pharmacia Biotech). The density of the bands was quantified with Image J software (RSB). Anti-GAPDH antibody was used as internal standard loading control (Santa Cruz Biotechnology, dilution 1: 1500).

\section{$\mathrm{Na}+\mathrm{K}+-\mathrm{ATPase}$ specific activity analysis}

Fifty mg samples of renal cortex were homogenized (1:10 weight/volume) in a solution containing $25 \mathrm{mM}$ imidazole/1 $\mathrm{mM}$ EDTA/0.25 $\mathrm{M}$ sucrose and centrifuged at $4700 \mathrm{~g}$ at $4^{\circ} \mathrm{C}$ for 15 minutes. ATPase activity was measured by colorimetric determination of the released orthophosphate and ouabain was used to specifically inhibit the $\mathrm{Na}+\mathrm{K}+$-ATPase activity according to Fiske-Subarrow's method, as previously described. (22)

\section{Statistical analysis}

The data were processed with the GraphPad Prism program, version 2.0. Gaussian distribution was evaluated by the Kolmogorov and Smirnov method and ANOVA followed by Newman-Keuls or Tukey tests was used to compare between the groups, as appropriate. Results were expressed as mean \pm SEM. Results with $\mathrm{p}<0.05$ were considered statistically significant.

\section{Ethical considerations}

All the experiments were carried out in accordance with the ethical norms of international regulations and the principles of care and use of experimental animals (protocol approved by CICUAL with Res. CD 2100-15, EXP-UBA: 0035638/15). At the beginning of the study rats were randomly assigned to 2 groups: a control group (C) with ad libitum tap water and a fructose group (F) with fructose (at $10 \% \mathrm{~W} / \mathrm{V}$ ) in the ad libitum drinking water for 4,8 and 12 weeks $(n=8$ rats per group and period).

\section{RESULTS}

Metabolic, hemodynamic and renal function parameters Plasma insulin values were significantly increased by the high fructose diet compared with control rats since week 4 of treatment, indicating presence of hyperinsulinemia (Table 1). Similarly, SBP values were significantly increased in the rats with high fructose diet compared with control rats since week 4 of treatment (Table 1). In the kidneys, fructose overload in the diet was associated with a significant increase in diuresis, as well as a reduction in sodium urinary excretion compared with control rats since week 4 of treatment (Table 1). Creatinine clearance was not significantly modified by fructose treatment in any experimental period. The presence of microalbuminuria as a marker of renal damage was observed in week 12 of fructose treatment (Table 1).

\section{Renal dopaminergic system}

A significant reduction in urinary dopamine excretion together with an increase of L-dopa excretion was observed in rats with high fructose diet compared with the control groups since week 4 of treatment. These changes caused a significant increase in the L-dopa/ urinary dopamine ratio since the same week (Table 1). A positive correlation was found between SBP and L-dopa/urinary dopamine ratio during the 12 -week study period $(\mathrm{R} 2=0.7816, \mathrm{p}=0.002)$.

\section{Specific activity and expression of renal $\mathrm{Na}+\mathrm{K}+-\mathrm{ATPase}$}

The specific activity of renal $\mathrm{Na}+/ \mathrm{K}+$-ATPase was significantly increased since week 4 of fructose treatment with respect to control rats (Table 1 ). The increase in activity was accompanied by an increase in protein expression by western blot (Figure 1).

\section{ANP system}

A significant decrease in plasma ANP concentration was observed in rats with high fructose diet at weeks 8 and 12 of treatment (Figure 2). In the kidneys, a decrease in NPRA expression was found since week 8 (Figure 3) together with an increase in NPRC expression since week 4 of treatment (Figure 4).

\section{DISCUSSION}

Metabolic syndrome is an entity that comprises a set 
Table 1. Effects of fructose treatment on metabolic, hemodynamic and renal parameters at 4, 8 and 12 weeks of treatment

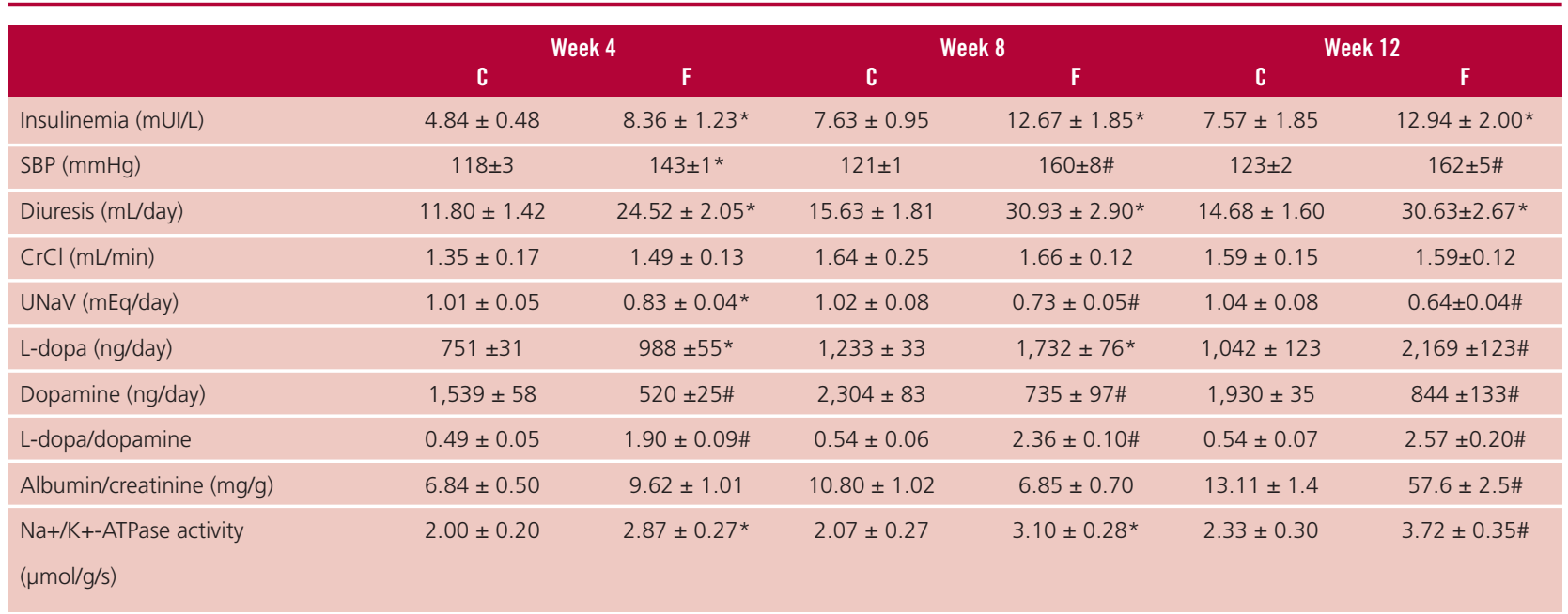

Fructose $(10 \% \mathrm{w} / \mathrm{v})$ was administered in the ad libitum drinking water. Values are indicated as mean \pm SEM ( $\mathrm{n}=8$ animals per group). C: Control; $\mathrm{F}$ : Fructose; SBP: Systolic blood pressure; CrCl: Creatinine clearance, UNaV: Urinary sodium excretion. * $\mathrm{p}<0.05$ vs. C; \#p $<0.01$ vs. C.

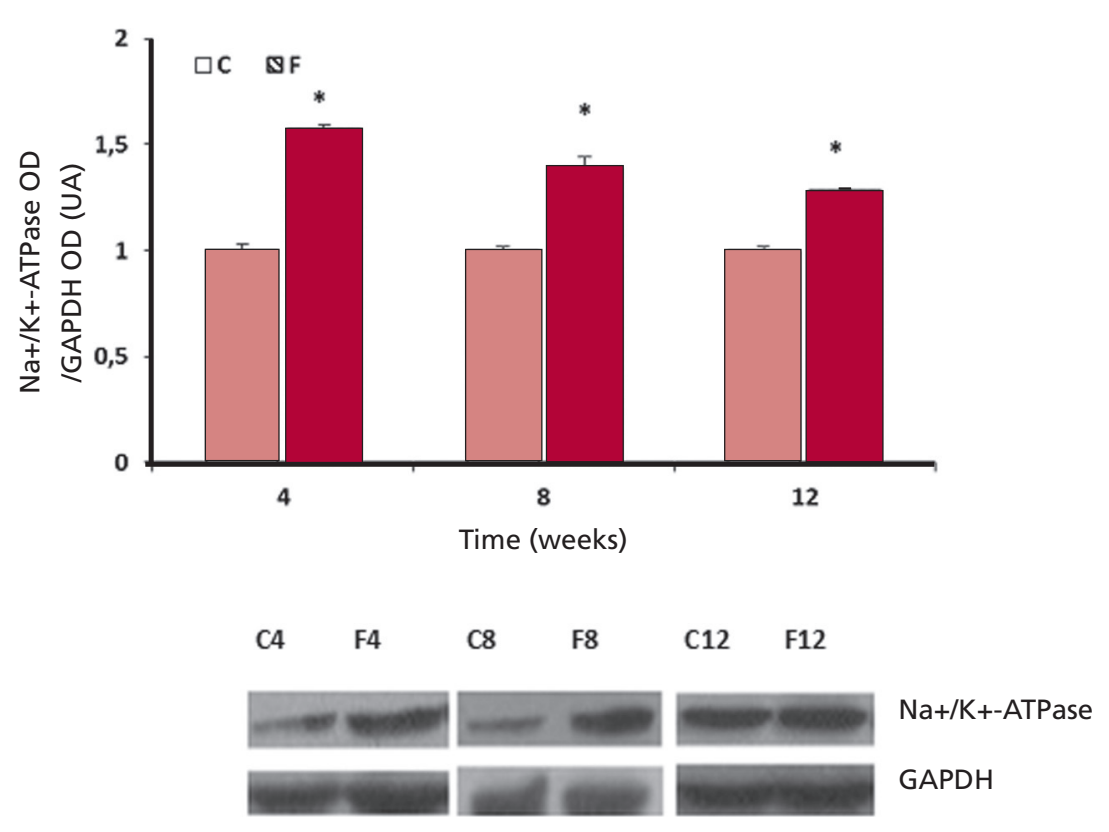

Fructose $(10 \% \mathrm{w} / \mathrm{v})$ was administered in the ad libitum drinking water. Values are indicated as mean \pm SEM ( $n=8$ animals per group). C: Control; F: Fructose. ${ }^{*} p<0.05$ vs. C group.

of disorders or metabolic abnormalities considered risk factors for the development of diabetes and cardiovascular disease. (1) It has been shown that rats fed a high fructose diet exhibit a large number of metabolic syndrome characteristics, such as insulin resistance, hyperinsulinemia and high blood pressure. (23) In our experiments, rats with a high fructose diet presented hyperinsulinemia, indicating the existence of insulin-resistance. The increase in SBP was detected after week 4 of fructose treatment and reached the highest blood pressure values at 8 and 12 weeks, with levels close to $160 \mathrm{mmHg}$. Systolic blood pressure levels were associated with a decrease in urinary sodium excretion since the same week, reflecting the state of saline retention in this experimental model. Although the exact mechanism by which hypertension develops in insulin-resistance conditions is still unknown, some studies suggest that hyperinsulinemia could cause sodium retention and an increase in sympathetic activity, key factors in the development of this disease. (24) Other authors suggest that the increase in renal reabsorption of sodium induced by insulin is enhanced 
Fig. 2. Plasma ANP levels in control and high fructose diet rats at 4, 8 and 12 weeks of treatment.
Fig. 3. A-type natriuretic peptide receptor protein expression in the kidneys of control and high fructose diet rats at 4, 8 and 12 weeks of treatment.

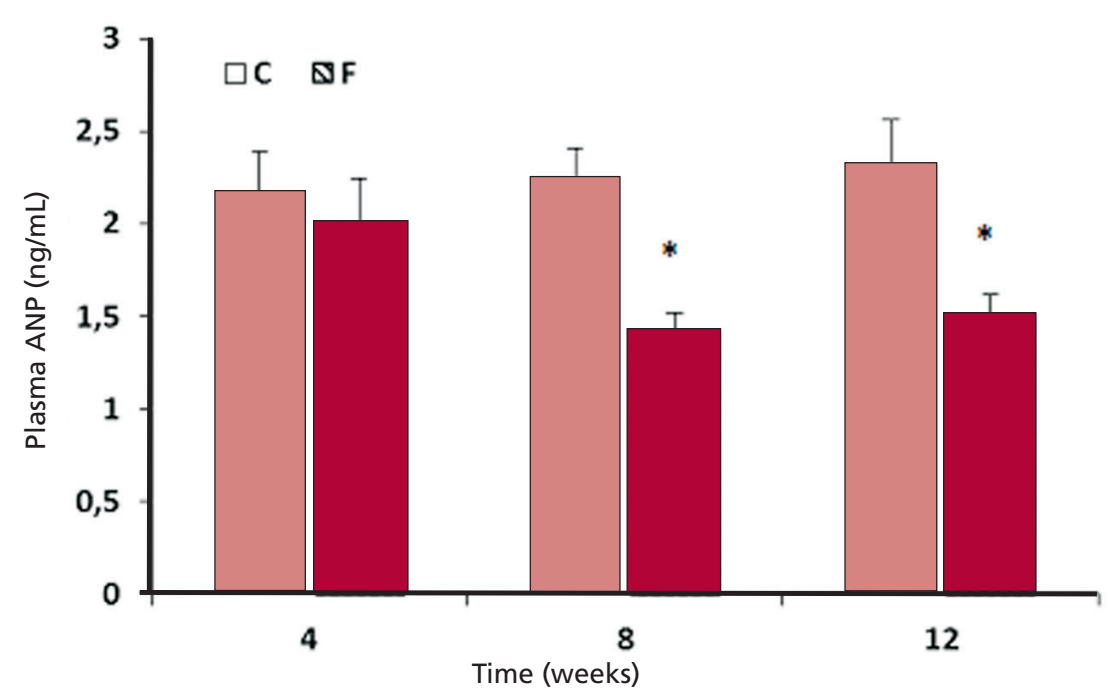

Fructose $(10 \% \mathrm{w} / \mathrm{v})$ was administered in the ad libitum drinking water. Values are indicated as mean \pm SEM ( $n=8$ animals per group). C: Control; F: Fructose; ANP: Atrial natriuretic peptide. * $p<0.05$ vs. $C$ group.
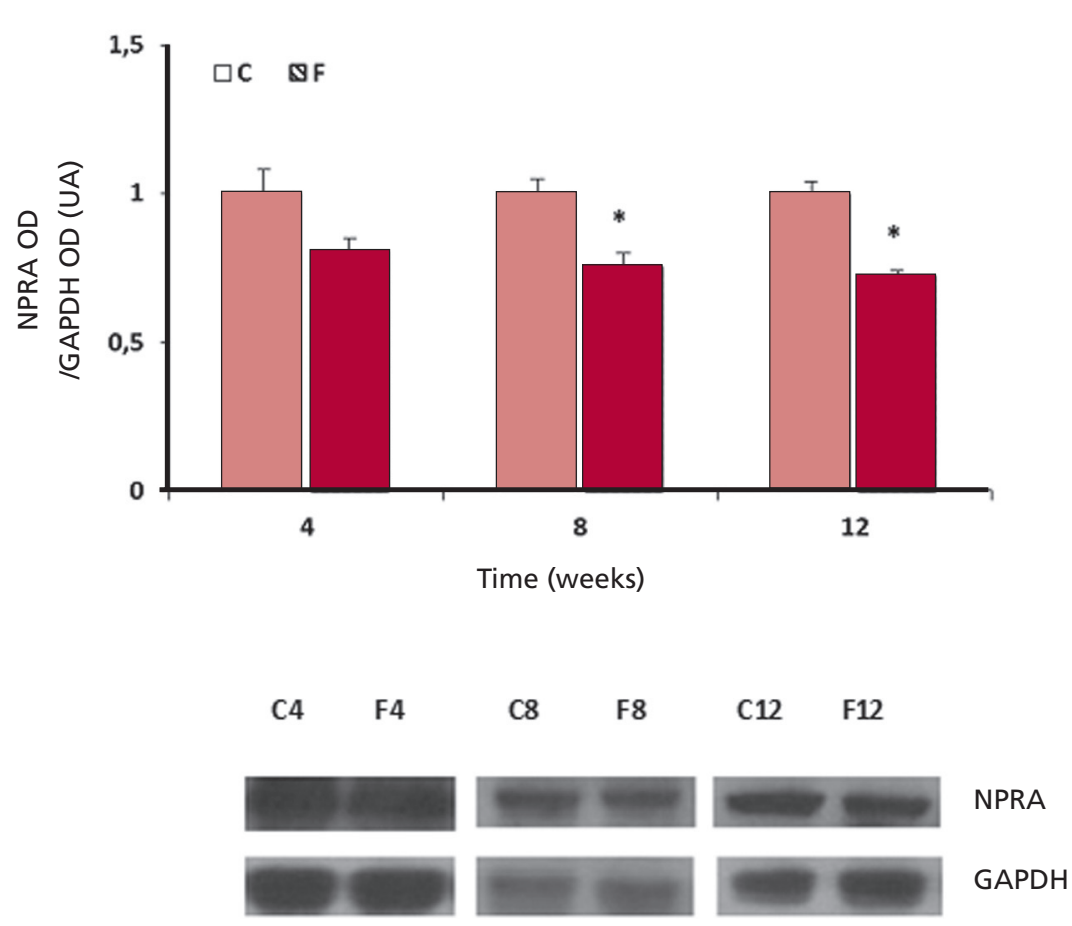

Fructose $(10 \% \mathrm{w} / \mathrm{v})$ was administered in the ad libitum drinking water. Values are indicated as mean \pm SEM ( $n=8$ animals per group). C: Control; F: Fructose; NPRA: A-type natriuretic peptide receptor. ${ }^{*} \mathrm{p}<0.05$ vs. $C$ group. in insulin resistance. Insulin stimulates all sodium transporters located in the proximal tubules, among them the $\mathrm{Na}+/ \mathrm{K}+-\mathrm{ATPase}$ pump, the type $3 \mathrm{Na}+\mathrm{H}+$ exchanger (NHE3), and the electrogenic basolateral cotransporter $\mathrm{Na}+\mathrm{HCO}-(\mathrm{NBCe} 1)$. (24) In our model, an increase in the specific activity of $\mathrm{Na}+\mathrm{K}+-\mathrm{AT}$ Pase enzyme was observed since week 4 of treatment, accompanied by an increase in its protein expression by western blot. These data are supported by other studies showing that $\mathrm{Na}+/ \mathrm{K}+-\mathrm{ATPase}$ is stimulated in insulin-resistance conditions and chronic exposure of renal cells to increased plasma insulin, which leads to greater sodium and water reabsorption, and, therefore, greater saline retention. (25) 


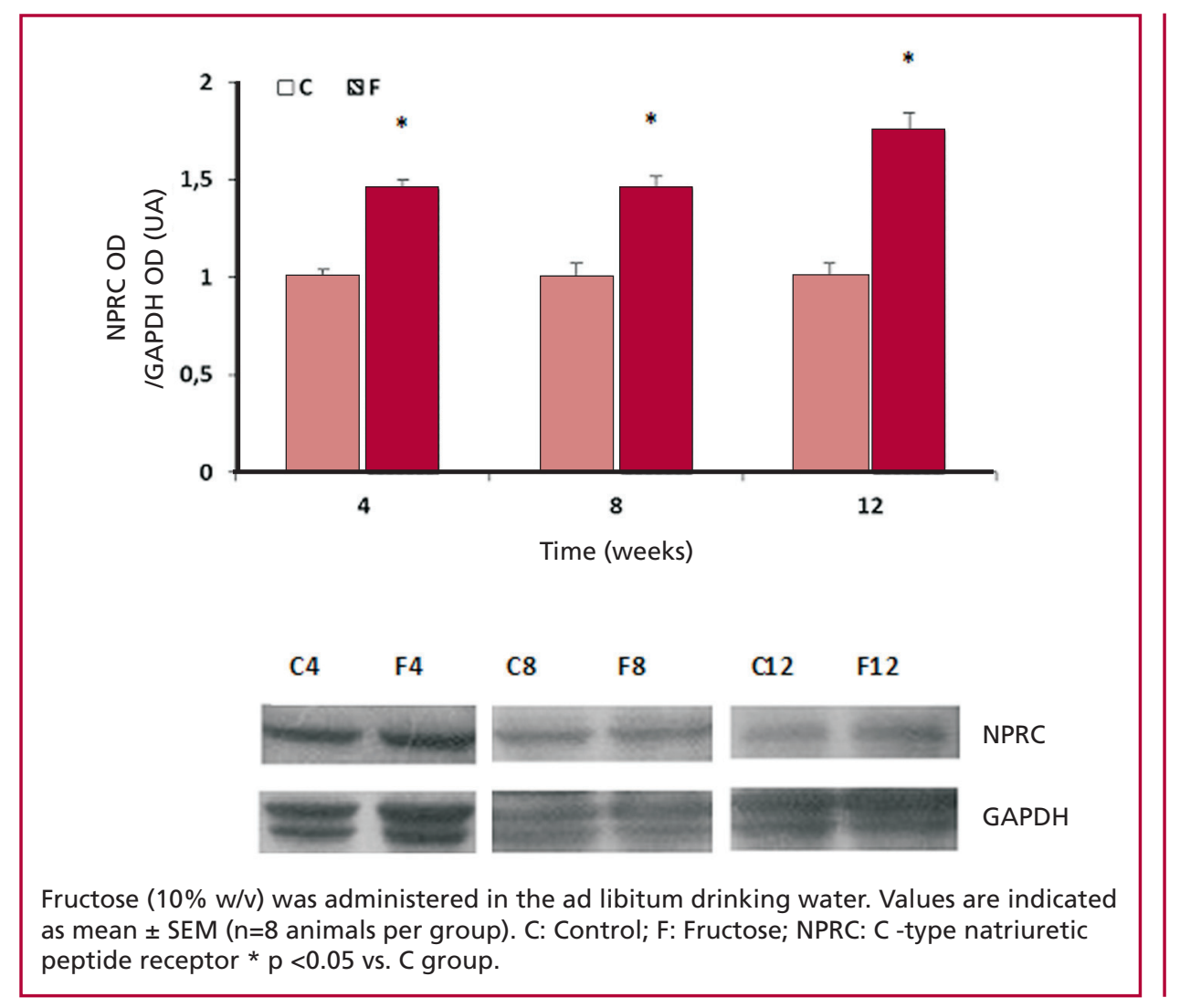

Fig. 4. C-type natriuretic peptide receptor protein expression in the kidneys of control and high fructose diet rats at 4,8 and 12 weeks of treatment.

A high fructose diet was associated with alterations in the natriuretic systems of renal dopamine and ANP. Regarding the renal dopaminergic system, a progressive increase in urinary L-dopa/ dopamine ratio was observed after week 4 of treatment, at the expense of an increase in the urinary excretion of Ldopa and a reduction of dopamine excretion. These changes would indicate the presence of reduced tubular uptake of L-dopa, a deficit of L-dopa conversion into dopamine in the tubular cells or a modification in the tubular release of the amine. In this sense, it has been shown that insulin stimulates the process of tubular L-dopa uptake and that this effect is abolished in rat models with insulin resistance due to fructose overload. (26) In another model of obesity-induced hyperinsulinemia, the presence of insulin resistance together with an increase in sympathetic tone was associated with lower renal dopaminergic activity. (27) The increase in urinary L-dopa/ dopamine ratio showed a positive correlation with the increase in SBP, thus being an adequate parameter that accompanies the increase in blood pressure levels in this model. Conversely, the ANP plasma concentration was significantly reduced since week 8 in rats with fructose overload, accompanied by a decrease in NPRA receptor expression. These results are consistent with the literature, where an association between low ANP levels, reduction in NPRA expression and states of insulin-resistance has been demonstrated. $(16,17,28) \mathrm{A}$ possible explanation for the reduction in plasma ANP concentration would be an increase in its degradation by NPRC receptors. In our study, NPRC expression was increased in the kidneys. In models of obesity and insulin resistance, the increased levels of NPRC described in adipose tissue would be responsible for the reduction of natriuretic peptide plasma levels in these conditions. (28) Likewise, the alteration of both natriuretic systems preceded in time the presence of microalbuminuria as a marker of renal structural damage in week 12; therefore, it can be postulated that the alteration of these systems would be associated with damage in this organ. Regarding this point, it has been described that renal dopamine regulates the inflammatory and oxidative condition through its D2 receptors, with an increase in proinflammatory and oxidative stress markers in models with receptor deficiency. (29) Additionally, it has been shown that ANP has antioxidant effects in rats by attenuating the levels of reactive oxygen species in a model of renal damage by ischemia-reperfusion. (30)

Our laboratory has shown that ANP stimulates dopamine uptake by tubular kidney cells, through the stimulation of NPRA receptors and protein kinase $G$ (PKG) activation. (11, 12, 22) Moreover, it has been shown that ANP increases the synthesis of renal dopamine by stimulating the activity of dopa decarboxylase. (31) In this insulin-resistance model, and as a result of low levels of plasma ANP, a reduction in both synthesis and uptake of dopamine by tubular cells would be expected as a consequence of reduced 
NPRA receptor expression in the kidneys. These effects would explain the decrease in the urinary excretion of dopamine and, therefore, the increase in the L-dopa/dopamine ratio observed in our experiments.

The results of the present work provide new evidence of the interaction between ANP and renal dopamine systems, so an association can be established between the reduction in urinary excretion of dopamine observed in this model of fructose overload in the diet and a depression in the ANP system. Similarly, it can be postulated that the alteration of both systems would be associated with the development of renal damage, taking into account that this preceded the appearance of renal structural injury evidenced by microalbuminuria at week 12 of fructose treatment.

\section{Conflicts of interest}

None declared. (See authors' conflicts of interest forms on the website/Supplementary material).

\section{REFERENCES}

1. DeFronzo RA, Ferrannini E. Insulin resistance - a multifactorial syndrome responsible for NIDDM, obesity, hypertension, dyslipidemia, and atherosclerotic cardiovascular disease. Diabetes Care 1991;14:173-94. http://doi.org/cw3z8h

2. Guzmán NJ. Epidemiology and management of hypertension in the Hispanic population: a review of the available literature. Am J Cardiovasc Drugs 2012;12:165-78.

3. Aperia A. Intrarenal dopamine: a key signal in the interactive regulation of sodium metabolism. Annu Rev Physiol 2000;62:62147. http://doi.org/f3xz7s

4. Beltowski J, Gorny D, Marciniak A. The mechanism of $\mathrm{Na}+, \mathrm{K}+-$ ATPase inhibition by atrial natriuretic factor in rat renal medulla. $\mathrm{J}$ Physiol Pharmacol 1998; 49:271-83.

5. Carey RM. Theodore Cooper Lecture: Renal DA system: paracrine regulator of sodium homeostasis and blood pressure. Hipertension 2001;38:297. http://doi.org/c9qpt2

6. Armando I, Villar VA, Jose PA. Dopamine and renal function and blood pressure regulation. Compr Physiol 2011; 1:1075-117. http:// doi.org/d3hjj4

7. Anand-Srivastava MB, Trachte GJ. Atrial natriuretic factor receptors and signal transduction mechanisms. Pharmacol Rev 1993;45:455-97.

8. Anand-Srivastava MB. Natriuretic peptide receptor-C signaling and regulation. Peptides 2005;26:1044-59. http://doi.org/fvthmk 9. Marin-Grez M, Briggs JP, Schubert G, Schnermann J. Dopamine receptor antagonists inhibit the natriuretic response to atrial natriuretic factor (ANF). Life Sci 1985; 36:2171-6. http://doi.org/c437bq 10. Petterson A, Hedner J, Hedner T. The diuretic effect of atrial natriuretic peptide (ANP) is dependent on dopaminergic activation. Acta Physiol Scand 1986; 126:619-21. http://doi.org/dndxs9

11. Fernández BE; Correa $\mathrm{AH}$; Choi MR. Atrial natriuretic factor stimulates renal dopamine uptake mediated by natriuretic peptidetype A receptor. Regul Pept 2005; 124:137-44. http://doi.org/ftb9pm 12. Correa AH, Choi MR, Gironacci M, Valera MS, Fernández BE. Signaling pathways involved in atrial natriuretic factor and dopamine regulation of renal $\mathrm{Na}+, \mathrm{K}+$-ATPase activity. Regul Pept 2007;138:26-31. http://doi.org/bpck37

13. De Fronzo RA: Insulin resistance, hyperinsulinemia and coro- nary artery disease. J Cardiovasc Pharmacol 1992;20:S1-S16. http:// doi.org/fbjzvw

14. Trivedi M, Marwaha A, Lokhandwala M. Rosiglitazone restores G-protein coupling, recruitment, and function of renal dopamine D1A receptor in obese Zucker rats. Hypertension 2004;43:376-82. http://doi.org/fbnnqs

15. Hasegawa K, Yoshida H, Ura N, Murakami H, Hagiwara M, Shimamoto $\mathrm{K}$. The role of renal natriuretic and depressor systems in insulin-resistant hypertensive rats. Hypertens Res 2004;27:501-8. http://doi.org/cbqn6h

16. Miyashita K, Itoh H, Tsujimoto H, Tamura N, Fukunaga Y, Sone M, et al. Natriuretic peptides/cGMP/cGMP-dependent protein kinase cascades promote muscle mitochondrial biogenesis and prevent obesity. Diabetes 2009;58:2880-92. http://doi.org/fqncmz

17. Olsen MH, Wachtell K, Tuxen C, Fossum E, Bang LE, Hall C, et al. Opposite effects of losartan and atenolol on natriuretic peptides in patients with hypertension and left ventricular hypertrophy: a LIFE substudy. J Hypertens 2005;23:1083-90. http://doi.org/fvw3sv 18. Gerstein HC, Mann JF, Yi Q, Zinman B, Dinneen SF, Hoogwerf $\mathrm{B}$, et al. Albuminuria and risk of cardiovascular events, death and hearth failure in diabetic and nondiabetic individuals. JAMA 2001;286:421-6. http://doi.org/crwp49

19. Gluba A, Mikhailidis DP, Lip GY, Hannam S, Rysz J, Banach M. Metabolic syndrome and renal disease. Int J Cardiol 2013;164:14150. http://doi.org/f4phvp

20. Locatelli F, Pozzoni P, Del Vecchio L. Renal Manifestations in the Metabolic Syndrome. J Am Soc Nephrol 2006;17:S81-5. http:// doi.org/fhvffm

21. Sarda IR, Wigle DA, Flynn TG, Pang SC. Radioimmunoassay for rat B-type natriuretic peptide (BNP-45). J Immunoassay 1993;14:167-82. http://doi.org/d7hsdd

22. Kouyoumdzian NM, Rukavina Mikusic NL, Kravetz MC, Lee BM, Carranza A, Del Mauro JS, et al. Atrial Natriuretic Peptide Stimulates Dopamine Tubular Transport by Organic Cation Transporters: A Novel Mechanism to Enhance Renal Sodium Excretion. PLoS One 2016; 11:e0157487. http://doi.org/gbqcbp

23. Wong SK, Chin KY, Suhaimi FH, Fairus A, Ima-Nirwana S. Animal models of metabolic syndrome: a review. Nutr Metab (Lond) 2016;13:65. http://doi.org/cncp

24. Horita S, Seki G, Yamada H, Suzuki M, Koike K, Fujita T. Insulin resistance, obesity, hypertension, and renal sodium transport. Int J Hypertens 2011;2011:391762. http://doi.org/cwcsks

25. Iannello S, Milazzo P, Belfiore F. Animal and human tissue $\mathrm{Na}, \mathrm{K}-\mathrm{ATPase}$ in normal and insulin-resistant states: regulation, behaviour and interpretative hypothesis on NEFA effects. Obes Rev 2007;8:231-51. http://doi.org/brg3mf

26. Carranza A, Mendez CF, Barontini M, Nowicki S. Insulin enhances L-dopa renal proximal tubule uptake: a regulatory mechanism impaired in insulin resistance. Pflugers Arch 2004;448:85-92. http://doi.org/fqmsww

27. Moreira-Rodrigues M, Quelhas-Santos J, Roncon-Albuquerque R, Serrão P, Leite-Moreira A, Sampaio-Maia B, Pestana M. Blunted renal dopaminergic system in a mouse model of dietinduced obesity. Exp Biol Med (Maywood) 2012;237:949-55. http://doi.org/f39hwp

28. Wang TJ, Larson MG, Levy D, et al. Impact of obesity on plasma natriuretic peptide levels. Circulation 2004;109:594 600. http://doi. org/bbqmdj

29. Armando I, Wang X, Villar VA, Jones JE, Asico LD. Hypertension 2007;49:672-8.

30. Koga H, Hagiwara S, Kusaka J, Matsumoto S, Nishida T, Yokoi I, et al. Human atrial natriuretic peptide attenuates renal ischemiareperfusion injury. J Surgical Res 2012; 173:348-53. http://doi.org/ bh54w8

31. Choi MR, Rukavina Mikusic NL, Kouyoumdzian NM, Kravetz MC, Fernández BE. Atrial natriuretic peptide and renal dopaminergic system: a positive friendly relationship? Biomed Res Int 2014;2014:710781. http://doi.org/dckpsn 